UDC 666.946:551.515

M.V. Kustov a, V.D. Kalugin a, V.V. Deineka ${ }^{a}$, G.M. Shabanova a , A.M. Korohodska ${ }^{b}$, E.D. Slepuzhnikov ${ }^{a}$, D.M. Deyneka ${ }^{b}$

\title{
RADIOPROTECTIVE CEMENT FOR LONG-TERM STORAGE OF NUCLEAR WASTE
}

\author{
a National University of Civil Defence of Ukraine, Kharkiv, Ukraine \\ b National Technical University «Kharkiv Polytechnic Institute», Kharkiv, Ukraine
}

To enhance the service safety of the geological repositories which are intended for a highly long-term storage of nuclear waste, we proposed coating the walls of repositories with a hermetically sealed radiation-resistant material. To this end, the compounds of a fourcomponent system $\mathrm{CaO}-\mathrm{BaO}-\mathrm{Fe}_{2} \mathrm{O}_{3}-\mathrm{SiO}_{2}$ were suggested. Based on these compounds, we developed the technology for the production of special polyfunctional corrosion-resistant cements that can be used for the production of extra strong radiation-protective and corrosion-resistant plugging cements. The thermodynamic analysis revealed probable phase equilibriums and enabled the tetrahedration of the system at the synthesis temperature of $1200^{\circ} \mathrm{C}$, which allowed minimizing the volume of required thermodynamic calculations. The processes of hydration of calcium-barium ferrosilicate cement were investigated. It was established that barium hydrosilicates and calcium and barium hydroferrites of a different basicity are the main hydration products; this provides high strength properties of the cement stone. The obtained materials are cements with a high strength (the compressive strength of $58.9 \mathrm{MPa}$ ), enhanced protective and corrosion-resistant properties (the calculated mass absorption coefficient and sulfate-resistance factor being equal to $247 \mathrm{~cm}^{2} / \mathrm{g}$ and 1.31, respectively). The protective concretes with different fillers, which were fabricated based on the developed cements, have a high strength (ultimate compressive strength of $58.4 \mathrm{MPa}$ ), a low level of softening in the temperature range of $20-1200^{\circ} \mathrm{C}$ (from 15 to $19 \%)$. They can be used at the service temperature of up to $1200^{\circ} \mathrm{C}$.

Keywords: radioactive waste, environmentally safe disposal, solid-phase synthesis, binding materials, hydration processes, radioprotective properties.

DOI: $10.32434 / 0321-4095-2020-129-2-73-81$

\section{Introduction}

The nuclear power engineering in Ukraine is a strategically important branch of power supply. In 2017, its contribution is about $50 \%$ of the total energy amount produced in Ukraine. Therefore, a successful operation of the nuclear power branch is one of indispensable prerequisites for ensuring national security.

A key principle of the handling of radioactive waste anticipates a high safety level [1]. Accidents at factories involving the use of radioactive materials lead to the appearance of vast contaminated areas [2]. Thus, serious environmental and economic problems appear.

Earlier, consideration was given to the opportunity of the long-term storage of radioactive waste at the deep-water sites of the great oceans.
However, the practice showed that these disposal technologies are associated with a great environmental danger for the great oceans [3]. In addition, the efficiency of the use of geological formations for the safe storage of long-term radioactive waste was established. Today, actually all the states that operate nuclear power plants are involved in an efficient development of the procedures for a long-term storage of radioactive waste. A comparative analysis of the technologies used for the radioactive waste disposal in European countries is given in ref. [5].

In 2011, International Atomic Energy Agency has worked out international rules and basic principles for the highly long-term storage of nuclear waste in geological formations [4]. The most appropriate sites for the construction of such depositories are 
considered to be geological rock salt formations [6] and volcanic rocks of more than 100,000 years old [7]. Each country considers the construction of geological depositories in its own territory based on the rock analysis $[8,9]$. For example, the United States makes use of exposed dense rocky strata $[10,11]$ and Germany and France organize geological depositories in industrial duffers [12].

When analyzing the available procedures used for the disposal of radioactive waste in geological formations, one should take into account an essential general drawback which is related to an extreme difficulty to provide the impermeability of geological formations exposed to underground waters and an easy approach to depressurized containers in case of emergency [13]. To increase the safety level of storage of radioactive waste, encapsulation in glass is recommended [14]. Ceramic materials show an increased efficiency for isolating radioactive materials from environmental influences [15]. One of the ways to the solution of the above problems is to coat the walls of depositories with the hermetically sealed material characterized by high radiation-resistant and corrosion-resistant properties.

Therefore, the aim of this work was to develop radiation-resistant and corrosion-resistant binding materials for the coating of the walls of underground depositories which are intended for the long-term storage of radioactive waste. To solve this problem, we studied the specific features of the hydration processes of the cements based on the compounds of the $\mathrm{CaO}-\mathrm{BaO}-\mathrm{Fe}_{2} \mathrm{O}_{3}-\mathrm{SiO}_{2}$ system; developed highly durable corrosion-resistant and radiationresistant concretes using proposed calcium-barium ferrosilicate cements and analyzed the physical, mechanical and service properties of the developed radiation-resistant and corrosion-resistant coatings.

\section{Material and methods}

To study the structure of four-component system and determine the direction of the reaction, we used the fundamental laws of equilibrium thermodynamics and thermodynamic methods of the analysis of chemical solid-phase reactions. To optimize the granulometric composition of the fillers and dry corrosion-resistant mixtures, we used the simplex-lattice method of experiment planning. The statistical processing of experimental data and those of thermodynamic computations was carried out using the Microsoft Office Excel software package.

The experimental investigation of the phase composition of clinker and hydration products was carried out using $\mathrm{X}$-ray phase analysis, petrographic analysis and thermographic analysis. The service properties of the developed materials were investigated using the standard techniques that are designed for the studies of binding materials.

To carry out the experimental investigation of the four-component $\mathrm{CaO}-\mathrm{BaO}-\mathrm{Fe}_{2} \mathrm{O}_{3}-\mathrm{SiO}_{2}$ system, we used the reagents that meet current home standards: calcium carbonate, barium carbonate, iron oxide and dehydrated silicon acid. We also used some technical raw materials: the chalk from the Bilogorsk deposit and the sand from Novovodolaga deposit. The following chemical industry wastes were used: barium-containing waste of the production of aminocapronic acid (the State Company "Chimreactive Plant», Kharkiv), the calciumcontaining water purification waste and the siliconcontaining waste of the production of ground bodies. The chemical compositions of the original components are listed in Table 1.

Thermodynamic output data were calculated using the well-known techniques. Specially developed computer software was used to process the results of the evaluation of compositions of the eutectics in the binary and ternary system sections, including the computation of the geometric and topological characteristics of phases.

The phase composition of the calcinated products and hydration products of the obtained

The chemical composition of the original components

Table 1

\begin{tabular}{l|c|c|c|c|c|c|c|c}
\hline \multicolumn{1}{c|}{ Material name } & \multicolumn{7}{c}{ Oxide content, wt.\% } \\
\cline { 2 - 8 } & $\mathrm{CaO}$ & $\mathrm{BaO}$ & $\mathrm{MgO}$ & $\mathrm{Al}_{2} \mathrm{O}_{3}$ & $\mathrm{Fe}_{2} \mathrm{O}_{3}$ & $\mathrm{SiO}_{2}$ & $\mathrm{R}_{2} \mathrm{O}$ & $\mathrm{f} .1$. \\
\hline $\begin{array}{l}\text { The calcium-containing water purification } \\
\text { waste }\end{array}$ & 44.82 & - & 13.88 & - & 1.95 & - & 2.52 & 36.83 \\
$\begin{array}{l}\text { Barium-containing waste of the production of } \\
\text { aminocapronic acid (state company } \\
\text { "Chimreactive Plant", Kharkiv) }\end{array}$ & - & 74.05 & - & 4.65 & - & - & - & 21.30 \\
$\begin{array}{l}\text { The silicon-containing waste of the production } \\
\text { of ground bodies }\end{array}$ & 2.46 & - & 1.64 & 1.43 & 0.66 & 91.74 & 2.07 & - \\
\hline $\begin{array}{l}\text { Iron-containing sludge PC ("ArselorMittal } \\
\text { Krivoy Rog") }\end{array}$ & 0.26 & - & 0.91 & 2.55 & 70.9 & 16.3 & 9.08 & - \\
\hline
\end{tabular}

M.V. Kustov, V.D. Kalugin, V.V. Deineka, G.M. Shabanova, A.M. Korohodska, E.D. Slepuzhnikov, D.M. Deyneka 
cements was determined by means of physicochemical methods of analysis, including petrographic (the polarization microscope MIN-8), scanning electron microscopy (scanning electron microscope REMMA-102), X-ray phase analysis (the DRON 3M device), and thermographic (the derivatograph R-1500D of Paulik-J., Paulik-L. and Erdey system) methods.

The physical and mechanical tests of the cements were carried out using the Strelkov method of small-size specimens. The optimal cement compositions were tested according to the standards DSTU EN 196-3:2007 and DSTU B V.2.7-86-99.

Thermal and thermomechanical properties of the cements and cement-based concretes were evaluated by means of standard techniques (DSTU B A.1.1-7-94).

The method developed by Kind was used to determine the sulfate-resistance coefficient. The method developed by Malinin was used for the evaluation of a decrease in the solid body-water system volume. The $\gamma$-quanta relaxation coefficient was determined by measuring the dose of braking $\gamma$-radiation on the transition side and backside of material specimens. The mass absorption coefficient of gamma radiation was derived from the following formula:

$$
\mathrm{I}=\mathrm{I}_{0} \mathrm{e}^{-\mu \times \rho},
$$

where $\mathrm{I}_{0}$ and $\mathrm{I}$ are the incident radiation intensity and the intensity of radiation that penetrates the material, respectively; $\rho$ is the density; $\chi$ is the thickness; and $\mu$ is the mass absorption coefficient.

To calculate the standard enthalpy of the formation $\left(\Delta \mathrm{H}_{298}^{0}\right)$ we suggested the method that takes into consideration the average gram-atomic enthalpy of the formation of the compounds that are included in the composition of the studied system.

\section{Results and discussion}

The obtained data showed that the splitting of the concentrated tetrahedron into elementary tetrahedrons at the temperature of $1200^{\circ} \mathrm{C}$ results in the coexistence of different phases in the fourcomponent $\mathrm{CaO}-\mathrm{BaO}-\mathrm{Fe}_{2} \mathrm{O}_{3}-\mathrm{SiO}_{2}$ system. These phases cause the existence of 15 «internal» conodes, i.e. those that pass through the $3 \mathrm{D}$ space of the concentrated tetrahedron: $\mathrm{Ba}_{2} \mathrm{SiO}_{4}-\mathrm{Ca}_{2} \mathrm{Fe}_{2} \mathrm{O}_{5}$; $\mathrm{Ba}_{2} \mathrm{SiO}_{4}-\mathrm{CaBaFe}_{4} \mathrm{O}_{8} ; \mathrm{CaSiO}_{3}-\mathrm{Ba}_{3} \mathrm{Fe}_{6} \mathrm{Si}_{2} \mathrm{O}_{16}$; $\mathrm{Ba}_{3} \mathrm{Fe}_{6} \mathrm{Si}_{2} \mathrm{O}_{16}-\mathrm{BaCa}_{2} \mathrm{Si}_{3} \mathrm{O}_{9} ; \mathrm{Ba}_{4} \mathrm{Fe}_{2} \mathrm{Si}_{4} \mathrm{O}_{15}-\mathrm{BaCa}_{2} \mathrm{Si}_{3} \mathrm{O}_{9}$; $\mathrm{Ba}_{3} \mathrm{Fe}_{6} \mathrm{Si}_{2} \mathrm{O}_{16}-\mathrm{Ca}_{3} \mathrm{Si}_{2} \mathrm{O}_{7} ; \mathrm{Ba}_{3} \mathrm{Fe}_{6} \mathrm{Si}_{2} \mathrm{O}_{16}-\mathrm{Ca}_{2} \mathrm{SiO}_{4}$; $\mathrm{Ba}_{3} \mathrm{Fe}_{6} \mathrm{Si}_{2} \mathrm{O}_{16}-\mathrm{Ba}_{5} \mathrm{Ca}_{3} \mathrm{Si}_{4} \mathrm{O}_{16} ; \mathrm{Ca}_{2} \mathrm{Fe}_{2} \mathrm{O}_{5}-\mathrm{Ba}_{5} \mathrm{Ca}_{3} \mathrm{Si}_{4} \mathrm{O}_{16}$; $\mathrm{Ca}_{2} \mathrm{Fe}_{2} \mathrm{O}_{5}-\mathrm{Ba}_{3} \mathrm{Fe}_{6} \mathrm{Si}_{2} \mathrm{O}_{16} ; \mathrm{Ba}_{3} \mathrm{Fe}_{6} \mathrm{Si}_{2} \mathrm{O}_{16}-\mathrm{CaFe}_{2} \mathrm{O}_{4}$; $\mathrm{Ba}_{3} \mathrm{Fe}_{6} \mathrm{Si}_{2} \mathrm{O}_{16}-\mathrm{CaFe}_{4} \mathrm{O}_{7} ; \mathrm{Ba}_{3} \mathrm{Fe}_{6} \mathrm{Si}_{2} \mathrm{O}_{16}-\mathrm{CaBaFe}_{4} \mathrm{O}_{8}$; $\mathrm{BaSiO}_{3}-\mathrm{CaBaFe}_{4} \mathrm{O}_{8}$ and $\mathrm{Ca}_{2} \mathrm{Fe}_{2} \mathrm{O}_{5}-\mathrm{BaSiO}_{3}$. These determine the availability of 38 elementary tetrahedrons in the subsolidus domain. The performed tetrahedration of the $\mathrm{CaO}-\mathrm{BaO}-\mathrm{Fe}_{2} \mathrm{O}_{3}-\mathrm{SiO}_{2}$ system revealed the phase equilibriums in the subsolidus at the temperature of $1200^{\circ} \mathrm{C}$ between all the compounds in their two-, three- and four-phase combinations. The coexistence of the phases was proved by both theoretical calculations and experimental data (the X-ray phase analysis of the calcinated products).

The next step was the triangulation of the $\mathrm{BaO}-\mathrm{Fe}_{2} \mathrm{O}_{3}-\mathrm{SiO}_{2}$ system with respect to seventeen stable phases that structurally form 17 elementary triangles. The $\mathrm{CaO}-\mathrm{Fe}_{2} \mathrm{O}_{3}-\mathrm{SiO}_{2}$ subsystem has nine stable phases and is split into 7 elementary triangles. The $\mathrm{CaO}-\mathrm{BaO}-\mathrm{SiO}_{2}$ subsystem has 15 phases and is split into 15 elementary triangles.

It was established that the composition of the $\mathrm{CaO}-\mathrm{BaO}-\mathrm{Fe}_{2} \mathrm{O}_{3}$ system includes eight binary compounds and one ternary compound. The subsystem is split into 16 elementary triangles that are stable before reaching the temperature of $1200^{\circ} \mathrm{C}$. The $\mathrm{Ca}_{3} \mathrm{SiO}_{5}$ compound was not taken into account due to the fact that it is dissociated in the presence of more than $0.5 \mathrm{wt} . \%$ of $\mathrm{BaO}$ with the release of a great amount of $\mathrm{CaO}$. The triangulation of the $\mathrm{CaO}-\mathrm{BaO}-\mathrm{Fe}_{2} \mathrm{O}_{3}-\mathrm{SiO}_{2}$ system at the temperature of $1200^{\circ} \mathrm{C}$ showed that it is split into 38 elementary tetrahedrons (Fig. 1).

To determine the geometric and topological characteristics of the system phases in full, we constructed the topological graph of the interrelation in the elementary tetrahedrons of the $\mathrm{CaO}-\mathrm{BaO}-\mathrm{Fe}_{2} \mathrm{O}_{3}-\mathrm{SiO}_{2}$ system (Fig. 2).

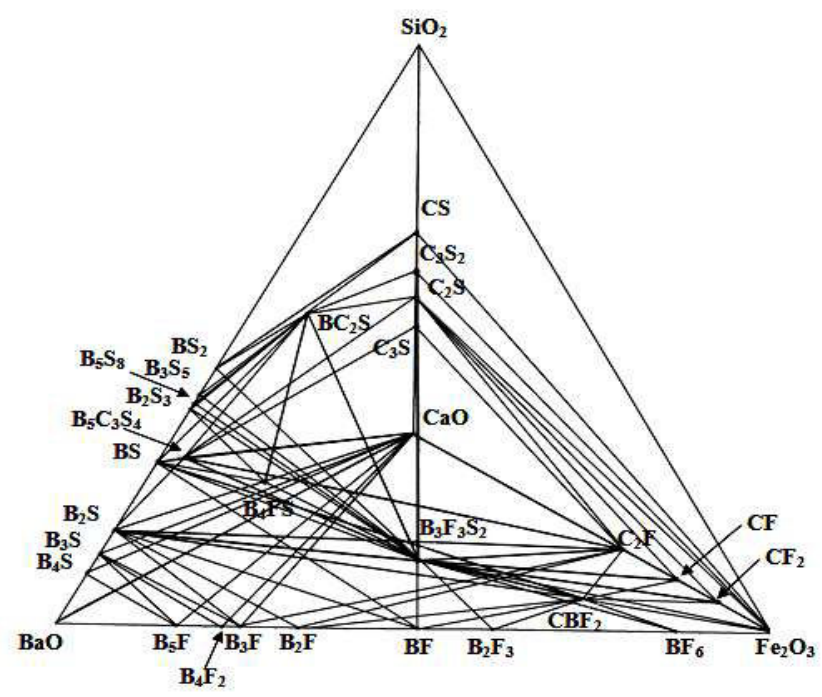

Fig. 1. Tetrahedration of the $\mathrm{CaO}-\mathrm{BaO}-\mathrm{Fe}_{2} \mathrm{O}_{3}-\mathrm{SiO}_{2}$ system at the temperature of $1200^{\circ} \mathrm{C}$ 


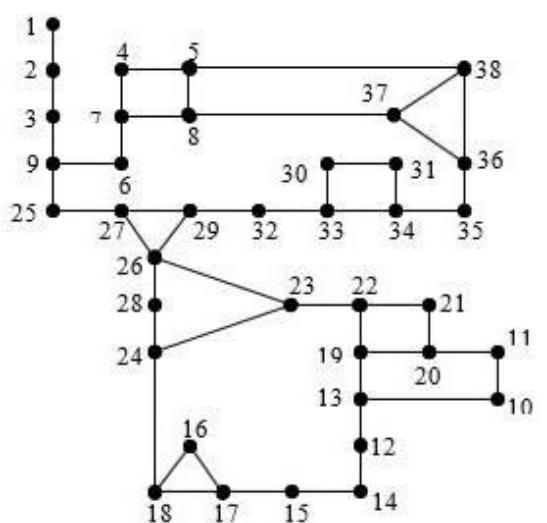

Fig. 2. Topological graph of the interrelation of the elementary tetrahedrons in the $\mathrm{CaO}-\mathrm{BaO}-\mathrm{Fe}_{2} \mathrm{O}_{3}-\mathrm{SiO}_{2}$ system

The geometric and topological analysis of the system showed that the most appropriate domain for the production of polyfunctional binding materials for a special purpose is restricted by a conventional tetrahedron with the vertexes that correspond to the following compounds: $\mathrm{Ba}_{2} \mathrm{Fe}_{2} \mathrm{O}_{5}, \mathrm{Ba}_{2} \mathrm{SiO}_{4}, \mathrm{Ca}_{2} \mathrm{Fe}_{2} \mathrm{O}_{5}$ and $\mathrm{Ba}_{5} \mathrm{Ca}_{3} \mathrm{Si}_{4} \mathrm{O}_{16}$ (No. 7, 17, 10 and 27, respectively).

The obtained data allow predicting the phase compositions of polyfunctional clinker cements having a set of specified properties.

We assessed the maximum temperatures of the treatment of the compositions used for the selected point of intersection of the $\mathrm{Ba}_{2} \mathrm{Fe}_{2} \mathrm{O}_{5}-\mathrm{Ba}_{2} \mathrm{SiO}_{4}-\mathrm{Ca}_{2} \mathrm{Fe}_{2} \mathrm{O}_{5}-\mathrm{Ba}_{5} \mathrm{Ca}_{3} \mathrm{Si}_{4} \mathrm{O}_{16}$ system by $\mathrm{CaO}-\mathrm{BaO}-\mathrm{Fe}_{2} \mathrm{O}_{3}-\mathrm{SiO}_{2}$. It was established that the obtained materials can be used until the temperature of $1200^{\circ} \mathrm{C}$ is reached.

It was established that $\mathrm{Ba}_{5} \mathrm{Ca}_{3} \mathrm{Si}_{4} \mathrm{O}_{16}$ manifests its binding properties under normal conditions and it has the strength of up to $23 \mathrm{MPa}$ after 28 days of the hardening. $\mathrm{BaCa}_{2} \mathrm{Si}_{3} \mathrm{O}_{9}$ shows relatively low binding properties and only under hydrothermal conditions (up to $5 \mathrm{MPa}$ after the autoclave treatment).

$\mathrm{Ba}_{3} \mathrm{Fe}_{6} \mathrm{Si}_{2} \mathrm{O}_{16}$ and $\mathrm{Ba}_{4} \mathrm{Fe}_{2} \mathrm{Si}_{4} \mathrm{O}_{15}$ compounds displayed no binding properties. The obtained data correlated with the crystalline structure of the threecomponent compounds under consideration.

To determine the physical, chemical and service properties of the cements based on the compositions available at the point of intersection of $\mathrm{Ba}_{2} \mathrm{Fe}_{2} \mathrm{O}_{5}-\mathrm{Ba}_{2} \mathrm{SiO}_{4}-\mathrm{Ca}_{2} \mathrm{Fe}_{2} \mathrm{O}_{5}-\mathrm{Ba}_{5} \mathrm{Ca}_{3} \mathrm{Si}_{4} \mathrm{O}_{16}$, a number of oxides were synthesized that include dibarium and dicalcium ferrites and dibarium silicate. Table 2 gives their chemical and mineralogical composition and Table 3 shows the physicalmechanical properties of the developed materials.

The test data of the given compositions of the clinkers show (Tables 1 and 2) that the obtained calcium-barium ferrosilicate cements are characterized by a uniform change in the volume during their hardening (the spread of the standard cone of the cement paste at the water-to-cement ratio $\mathrm{W} / \mathrm{C}=0.5$ varies in the range of 190 to $210 \mathrm{~mm}$ ) and they are extra-strong. The compressive strength is in the range of 27.4 to $58.9 \mathrm{MPa}$ and the bending strength is in the range of 5.2 to $6.8 \mathrm{MPa}$. These cements are fast-hardening. After the 3 days of the hardening, their compressive strength is 16 to 48.6 MPa. They are also hydraulic binders with the $\mathrm{W} / \mathrm{C}$ ratio of 0.17 to 0.38 that have a high mass absorption coefficient of 213 to $287 \mathrm{~cm}^{2} / \mathrm{g}$. Their

Table 2

Chemical and mineralogical composition of the clinkers of $\mathrm{Ba}_{2} \mathrm{Fe}_{2} \mathrm{O}_{5}-\mathrm{Ba}_{2} \mathrm{SiO}_{4}-\mathrm{Ca}_{2} \mathrm{Fe}_{2} \mathrm{O}_{5}-\mathrm{Ba}_{5} \mathrm{Ca}_{3} \mathrm{Si}_{4} \mathrm{O}_{16}$ section

\begin{tabular}{c|c|c|c|c|c|c|c|c}
\hline \multirow{2}{*}{$\begin{array}{c}\text { Composition } \\
\text { number }\end{array}$} & \multicolumn{2}{|c|}{ Chemical composition, wt.\% } & \multicolumn{5}{c}{ Mineralogical composition, wt.\% } \\
\cline { 2 - 9 } & $\mathrm{CaO}$ & $\mathrm{SiO}_{2}$ & $\mathrm{BaO}$ & $\mathrm{Fe}_{2} \mathrm{O}_{3}$ & $\mathrm{Ba}_{2} \mathrm{SiO}_{4}$ & $\mathrm{Ba}_{2} \mathrm{Fe}_{2} \mathrm{O}_{5}$ & $\mathrm{Ca}_{2} \mathrm{Fe}_{2} \mathrm{O}_{5}$ & $\mathrm{Ba}_{5} \mathrm{Ca}_{3} \mathrm{Si}_{4} \mathrm{O}_{16}$ \\
\hline 1 & 22.69 & 7.38 & 27.62 & 32.31 & 45 & - & 55 & - \\
\hline 2 & 20.68 & 8.20 & 41.80 & 29.37 & 50 & - & 50 & - \\
\hline 3 & 18.57 & 9.02 & 45.98 & 26.43 & 55 & - & 45 & - \\
\hline 4 & 16.50 & 9.84 & 50.16 & 23.50 & 60 & - & 40 & - \\
\hline 5 & - & 8.19 & 74.69 & 17.12 & 50 & 50 & - & - \\
\hline 6 & - & 4.10 & 70.22 & 25.68 & 25 & 75 & - & - \\
\hline 7 & - & 6.55 & 72.90 & 20.55 & 40 & 60 & - & - \\
\hline 8 & - & 12.30 & 79.14 & 8.56 & 75 & 25 & - & - \\
\hline 9 & 10.31 & - & 49.32 & 40.37 & - & 75 & 25 & - \\
\hline 10 & 20.63 & - & 32.88 & 46.49 & - & 50 & 50 & - \\
\hline 11 & 30.94 & - & 16.44 & 52.62 & - & 25 & 75 & - \\
\hline 12 & 4.13 & 13.11 & 73.45 & 9.30 & 80 & 10 & 10 & - \\
\hline 13 & 4.13 & 11.48 & 71.67 & 12.72 & 70 & 20 & 10 & - \\
\hline 14 & 16.50 & 3.28 & 43.02 & 37.20 & 20 & 40 & 40 & - \\
\hline 15 & 2.50 & 7.38 & 69.57 & 20.55 & 20 & 60 & - & 20 \\
\hline
\end{tabular}

M.V. Kustov, V.D. Kalugin, V.V. Deineka, G.M. Shabanova, A.M. Korohodska, E.D. Slepuzhnikov, 
Table 3

Physical-mechanical properties of calcium-barium ferrosilicate cements

\begin{tabular}{|c|c|c|c|c|c|c|c|c|c|}
\hline \multirow{2}{*}{$\begin{array}{l}\text { Composition } \\
\text { number }\end{array}$} & \multirow[t]{2}{*}{$\mathrm{W} / \mathrm{C}$} & \multicolumn{2}{|c|}{$\begin{array}{l}\text { Setting time, } \\
\text { hours-minutes }\end{array}$} & \multicolumn{3}{|c|}{$\begin{array}{c}\text { Ultimate compressive strength, } \\
\mathrm{MPa} \text { at various ages }\end{array}$} & \multirow{2}{*}{$\begin{array}{l}\text { Ultimate bending } \\
\text { strength, } \mathrm{MPa}\end{array}$} & \multirow[t]{2}{*}{$\mu, \mathrm{cm}^{2} / \mathrm{g}$} & \multirow[t]{2}{*}{$\mathrm{KF}$} \\
\hline & & initial & Final & 3 days & 7 days & 28 days & & & \\
\hline 1 & 0.38 & $1-52$ & $3-22$ & 44.1 & 47.1 & 48.9 & 5.4 & 227 & 1.17 \\
\hline 2 & 0.35 & $1-54$ & $3-23$ & 42.9 & 49.0 & 51.5 & 5.8 & 231 & 1.20 \\
\hline 3 & 0.35 & $1-56$ & $3-24$ & 43.8 & 50.3 & 53.0 & 6.1 & 236 & 1.25 \\
\hline 4 & 0.34 & $2-00$ & $3-25$ & 44.5 & 51.0 & 55.0 & 6.7 & 240 & 1.29 \\
\hline 5 & 0.22 & $1-25$ & 4-05 & 40.0 & 48.4 & 52.3 & 5.9 & 283 & 1.20 \\
\hline 6 & 0.24 & $2-10$ & $3-14$ & 45.8 & 50.6 & 54.4 & 6.0 & 287 & 1.19 \\
\hline 7 & 0.20 & $2-55$ & $4-20$ & 44.5 & 46.0 & 51.2 & 5.7 & 285 & 1.23 \\
\hline 8 & 0.20 & $1-40$ & $2-55$ & 31.4 & 42.0 & 46.4 & 5.3 & 279 & 1.17 \\
\hline 9 & 0.18 & $3-65$ & $4-35$ & 16.0 & 20.6 & 27.5 & 5.2 & 265 & 1.18 \\
\hline 10 & 0.19 & $2-40$ & $3-50$ & 25.0 & 38.0 & 52.0 & 5.9 & 239 & 1.23 \\
\hline 11 & 0.22 & $2-00$ & $3-35$ & 22.3 & 35.6 & 40.7 & 5.7 & 213 & 1.15 \\
\hline 12 & 0.17 & $0-15$ & $1-30$ & 16.3 & 20.6 & 27.5 & 5.9 & 268 & 1.20 \\
\hline 13 & 0.19 & $2-40$ & $3-50$ & 24.5 & 30.4 & 42.2 & 6.1 & 269 & 1.30 \\
\hline 14 & 0.21 & $1-55$ & $3-20$ & 48.6 & 51.2 & 58.9 & 6.8 & 247 & 1.31 \\
\hline 15 & 0.19 & $2-40$ & $3-50$ & 16.3 & 22.0 & 27.4 & 5.8 & 277 & 1.28 \\
\hline
\end{tabular}

sulfate resistance coefficient varies in the range of 1.17 to 1.31 . It was established that the water-tocement ratio, the mass absorption coefficient and the sulfate resistance coefficient increase with an increase in the content of barium oxide in the cements.

Based on the obtained data, we arrived at a conclusion that an optimal composition is that having No. 14 in Table 2, it corresponds to the ratio of $\mathrm{Ba}_{2} \mathrm{Fe}_{2} \mathrm{O}_{5}: \mathrm{Ba}_{2} \mathrm{SiO}_{4}: \mathrm{Ca}_{2} \mathrm{Fe}_{2} \mathrm{O}_{5}=2: 1: 2$. Further, we studied the nature of the phases in the cement clinker with an optimal composition. It was established that the main phases of the test cement are dibarium and dicalcium ferrites and dibarium silicate.

The phase-formation processes of cements in the raw material mixture were studied, this mixture included calcium carbonate, barium carbonate, iron oxide and silicon oxide. The temperature $(900,1000$ and $1100^{\circ} \mathrm{C}$ ) and isothermal holding time $(15,30$, 60 and 180 minutes) were taken as variable factors. It was determined that the reactions of calcium and barium oxides with silicon and iron oxides started at a noticeable rate already at $900^{\circ} \mathrm{C}$ and ceased at $1100^{\circ} \mathrm{C}$.

The clinker phase-formation process rate constant was calculated and it was established that this phase-formation process occurred due to solidphase reactions, the rate of which is satisfactorily described by the Ginstling-Brownstein equations.

The X-ray phase analysis of the cements that were synthesized at different temperatures and different holding time showed that a metastable phase is initially formed in raw-material mixtures that include calcium carbonate, barium carbonate, iron oxide and silicon oxide. This metastable phase is a three-component compound $\mathrm{Ba}_{5} \mathrm{Ca}_{3} \mathrm{Si}_{4} \mathrm{O}_{16}$ that is further decomposed into $\mathrm{Ba}_{2} \mathrm{Fe}_{2} \mathrm{O}_{5}, \mathrm{Ba}_{2} \mathrm{SiO}_{4}$, and $\mathrm{Ca}_{2} \mathrm{Fe}_{2} \mathrm{O}_{5}$ (Fig. 3).

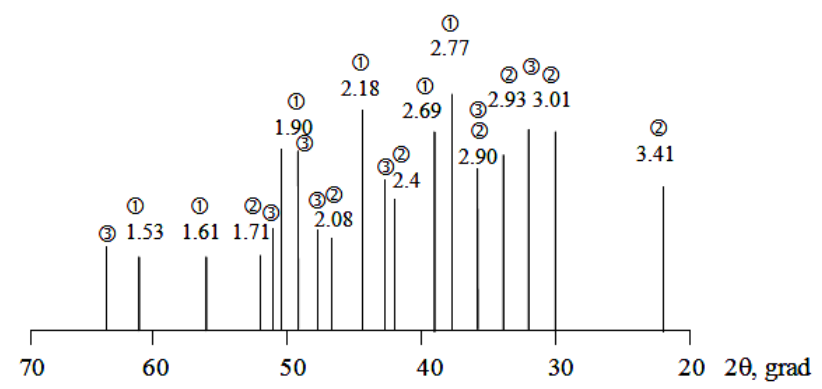

Fig. 3. Dashed X-ray diffraction pattern of the clinker phase with the optimal composition $1-\mathrm{Ba}_{2} \mathrm{Fe}_{2} \mathrm{O}_{5} ; 2-\mathrm{Ba}_{2} \mathrm{SiO}_{4}$;

$$
3-\mathrm{Ca}_{2} \mathrm{Fe}_{2} \mathrm{O}_{5}
$$

The X-ray phase analysis was also used to study the products of hydration of the calcium-barium ferrosilicate cement (Fig. 4). It was established that the hydration of the test cement proceeds according to the hydration of individual phases that are peculiar for the clinker composition. The composition of the hydrated calcium-barium ferrosilicate cement represents a complicated conglomerate of the new hydrate formations of barium silicates and calcium and barium ferrites and also barium and iron hydroxides both in colloidal and crystalline states. The combination of them provides high strength characteristics for the hardened cement stone. 


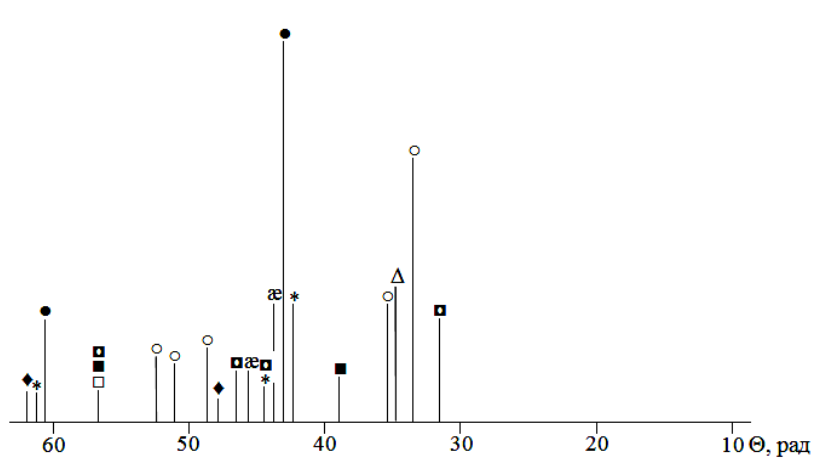

Fig. 4. Dashed X-ray diffraction pattern of the hydrated cement: - $-\mathrm{Ba}_{2} \mathrm{SiO}_{4} ; \bigcirc-\mathrm{Ba}_{2} \mathrm{Fe}_{2} \mathrm{O}_{5} ; \mathbf{-}-\mathrm{BSH}$;

$\triangle-\mathrm{BaSiO}_{3} \cdot 6 \mathrm{H}_{2} \mathrm{O} ;$ H $-\mathrm{BaFe}_{2} \mathrm{O}_{4} \cdot 5 \mathrm{H}_{2} \mathrm{O} ;-\mathrm{BaO} \cdot 2 \mathrm{H}_{2} \mathrm{O}$;

• - $\mathrm{Fe}_{2} \mathrm{O}_{3} \cdot 3 \mathrm{H}_{2} \mathrm{O} ; \mathbf{\square}-\mathrm{CaFe}_{4} \mathrm{O}_{7} \cdot 13 \mathrm{H}_{2} \mathrm{O}$

In order to develop resource-saving and energysaving technologies, we studied calcium-, barium-, and silicon-containing wastes supplied by different branches of industry. It was stated that the chemical composition of barium-containing waste from the production of aminocapronic acid, calciumcontaining water purification waste and the siliconcontaining waste from the production of ground bodies can be used as original raw materials for the production of special polyfunctional binding substances. The cements, that were obtained using the waste, are characterized by the following setting periods: the initial period is equal to 1 hour 50 minutes and the finish period is equal to 3 hours 30 minutes. The compressive strength at the age of 28 days of the hardening is 50 to $60 \mathrm{MPa}$. The calculated mass-absorption coefficient is $200 \mathrm{~cm}^{2} / \mathrm{g}$, depending on the phase composition. The corrosionresistance is 1.1 to 1.2 .

The technology for the production of corrosion- resistant barium-containing binding materials of a special purpose that are based on the chemical industry waste is resource saving and energy saving. It may considerably improve the environmental conditions in the industrial Ukrainian regions. This process allows utilizing critical raw materials that will result in a considerable decrease in the cost price of the finished products without any additional capital expenditures.

To produce the protective concrete layer with high strength, density and homogeneity, we selected an optimal granulometric composition at the ratio of cement to aggregate equal to $3: 1$. Natural (barite and serpentinite) and synthesized (monosilicate and barium monoferrite) materials were used as fillers.

To provide high strength, density and uniformity of the concretes, it was necessary to obtain a mixture consisting of three fractions of aggregates with the following content: (1) fraction with the grain sizes

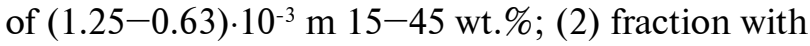
the grain sizes of $(0.63-0.315) \cdot 10^{-3} \mathrm{~m} 15-45 \mathrm{wt} . \%$; and (3) fraction with the grain sizes of $(0.315-$ $0.15) \cdot 10^{-3} \mathrm{~m} \mathrm{25-55}$ wt.\%.

Table 4 shows the basic physical-mechanical properties of the prepared protective coatings with suitable compositions.

It was established that barium monosilicate is the most efficient filler; it is characterized by the matrix affinity to the cement composition. The thermomechanical properties of the developed concretes meet the requirements to the protective materials, therefore high internal expansion strains would not arise in the external zone in the case of the temperature difference through the concrete bulk.

Since the developed calcium-barium ferrosilicate cement is characterized by a high compressive strength and bending strength and has

Table 4

Physical-mechanical properties of protective concrete layers

\begin{tabular}{|c|c|c|c|c|}
\hline \multirow[b]{2}{*}{ Parameters } & \multicolumn{4}{|c|}{ Fillers } \\
\hline & $\begin{array}{l}\text { Barium monosilicate } \\
\mathrm{BaSiO}_{3}\end{array}$ & $\begin{array}{l}\text { Barium monoferrite } \\
\mathrm{Ba}_{2} \mathrm{FeO}_{3}\end{array}$ & $\begin{array}{l}\text { Barite } \\
\mathrm{BaSO}_{4}\end{array}$ & $\begin{array}{c}\text { Serpentinite } \\
(\mathrm{Mg}, \mathrm{Fe})_{3} \mathrm{Si}_{2} \mathrm{O}_{5}(\mathrm{OH})_{4}\end{array}$ \\
\hline \multirow{4}{*}{$\begin{array}{l}\text { Compressive strength, } \mathrm{MPa} \\
\text { at the age of } 1 \text { day } \\
3 \text { days } \\
7 \text { days } \\
28 \text { days }\end{array}$} & 45.4 & 39.9 & 31.3 & 29.9 \\
\hline & 49.4 & 45.1 & 35.3 & 33.7 \\
\hline & 58.4 & 48.0 & 42.1 & 39.6 \\
\hline & 58.4 & 55.8 & 47.3 & 44.5 \\
\hline Porosity, $\%$ & 17.1 & 17.6 & 17.0 & 18.6 \\
\hline Density, $\mathrm{kg} / \mathrm{m}^{3}$ & 4400 & 4680 & 4540 & 2820 \\
\hline $\begin{array}{l}\text { Coefficient of gamma-quanta } \\
\text { transmission }\end{array}$ & 0.46 & 0.52 & 0.50 & 0.51 \\
\hline $\begin{array}{l}\text { Compressive strength of irradiated } \\
\text { specimens, } \mathrm{MPa}\end{array}$ & 62.2 & 60.2 & 36.8 & 41.2 \\
\hline
\end{tabular}

M.V. Kustov, V.D. Kalugin, V.V. Deineka, G.M. Shabanova, A.M. Korohodska, E.D. Slepuzhnikov, D.M. Deyneka 
Table 5

Physical-mechanical properties of grouts

\begin{tabular}{l|c|c|c|c}
\hline \multirow{2}{*}{ Parameters } & \multicolumn{3}{c}{ Fillers } \\
\cline { 2 - 5 } & $\begin{array}{c}\text { Barium monosilicate } \\
\mathrm{BaSiO}_{3}\end{array}$ & $\begin{array}{c}\text { Barium monoferrite } \\
\mathrm{Ba}_{2} \mathrm{FeO}_{3}\end{array}$ & $\begin{array}{c}\text { Barite } \\
\mathrm{BaSO}_{4}\end{array}$ & $\begin{array}{c}\text { Serpentinite } \\
\left(\mathrm{Mg}, \mathrm{Fe}_{3} \mathrm{Si}_{2} \mathrm{O}_{5}(\mathrm{OH})_{4}\right.\end{array}$ \\
\hline $\begin{array}{l}\text { Concentration, } \mathrm{cm}^{3} / \mathrm{g} \\
\begin{array}{l}\text { Compressive strength, } \mathrm{MPa} \text {, at the age } \\
\text { of 28 days of the hardening in water }\end{array}\end{array}$ & 7.0 & 6.09 & 0.07 & 0.12 \\
\hline $\begin{array}{l}\text { Compressive strength, } \mathrm{MPa} \text { after 6 } \\
\text { months of holding in 3\% } \mathrm{MgSO}\end{array}$ & 7.1 & 6.1 & 9.5 & 6.2 \\
\hline $\begin{array}{l}\text { Sulfate resistance coefficient } \\
\text { Strength after the autoclave treatment, } \\
\text { MPa }\end{array}$ & 1.01 & 0.95 & 1.32 & 5.3 \\
\hline $\begin{array}{l}\text { Standard paste cone spread at W/C } \\
\text { ratio=0.5 mm }\end{array}$ & 6.7 & 5.3 & 7.0 & 0.85 \\
\hline
\end{tabular}

a high sulfate-resistance, the cements with various fillers were synthesized to obtain the grout solution. Table 5 gives the physical, mechanical and technical properties of grouts. The test data show that the grout solution with the barite filler, that enhances the corrosion resistance of the material, has the highest bending strength, the lowest shrinkage during the setting and the highest sulfate-resistance.

The tests of the grout solution were carried out using barite by the factory SKP «Monolith» (Konstiantynivka, Donetsk region, Ukraine). The obtained results showed that the grouts produced using the calcium-barium ferrosilicate cement with an optimal composition are high-strength and corrosion-resistant structural materials that can be also used for the insulation of the «hot» oil and gas well holes.

\section{Conclusions}

1. The $\mathrm{CaO}-\mathrm{BaO}-\mathrm{Fe}_{2} \mathrm{O}_{3}$ system was subjected to its total triangulation at the temperature of $1200^{\circ} \mathrm{C}$. It was established that the system was split into 16 elementary triangles.

2. The conditions for the hardening of the triple compounds of the $\mathrm{CaO}-\mathrm{BaO}-\mathrm{Fe}_{2} \mathrm{O}_{3}-\mathrm{SiO}_{2}$ system were theoretically calculated and experimentally determined. It was established that $\mathrm{Ba}_{5} \mathrm{Ca}_{3} \mathrm{Si}_{4} \mathrm{O}_{16}$ displayed cementing properties under normal conditions and it had the strength of $23 \mathrm{MPa}$ after 28 days of the hardening. $\mathrm{BaCa}_{2} \mathrm{Si}_{3} \mathrm{O}_{9}$ showed low cementing properties only under hydrothermal conditions (up to $5 \mathrm{MPa}$ after the autoclave treatment).

3. The specific features of the phase-formation processes in the raw-material mixture, which consists of calcium carbonate, barium carbonate, iron oxide and silicon oxide, have been investigated. It was stated that the solid-phase reactions occurred initially at a noticeable rate already at the temperature of $900^{\circ} \mathrm{C}$; however, they were totally completed at the temperature of $1100^{\circ} \mathrm{C}$.

4. The features of the hydration processes of calcium-barium ferrosilicate cement were studied. The main hydration products are barium hydrosilicates and calcium with different degree of basicity, and barium ferrites, barium and iron hydroxides in colloidal and crystalline states that provide high strength characteristics for the hardened cement stone.

5. The resource-saving and energy-saving technology for the production of packing cement was developed using the waste of chemical industry as an original raw material.

6. New compositions for corrosion-resistant concretes with a high level of $\gamma$-radiation protection were developed using artificially synthesized (barium monosilicate) and natural (barite and serpentinite) fillers. Physical and physical-mechanical characteristics of the concretes of a special purpose were determined. For instance, their compressive strength after 28 days of hardening was in the range of 44.5 to $58.4 \mathrm{MPa}$; the porosity was 17 to $18,6 \%$; the volumetric weight was 2820 to $4680 \mathrm{~kg} / \mathrm{m}^{3}$, the $\gamma$-radiation transmission coefficient was 0.46 to 0.52 , and the softening degree in the temperature interval of 0 to $1200^{\circ} \mathrm{C}$ was 15 to $19 \%$. These parameters ensure using the developed compositions as protective coatings for the underground depositories intended for a highly long-term disposal of radioactive waste.

\section{REFERENCES}

1. Mollah A.S. Overview of regulatory control for radioactive sources and nuclear materials for peaceful applications of nuclear technology // Int. J. Nucl. Law. - 2009. - Vol.2. - No. 3. P. 175-191. 
2. Procedure for implementation of the method of artificial deposition of radioactive substances from the atmosphere / Kustov M., Slepuzhnikov E., Lipovoy V., Khmyrov I., Dadashov I., Buskin O. // Nucl. Radiat. Saf. - 2019. No. 3(83). - P.13-25.

3. Aust M.-O., Herrmann J. Summary of the situation of dumped nuclear waste in the North-East Atlantic Ocean. OSPAR Commission, 2013. $-29 \mathrm{p}$.

4. Borowski G., Wosko M. Ecological and technical requirements of radioactive waste utilisation // J. Ecol. Eng. 2013. - Vol.14. - No. 1. - P.40-47.

5. Lidskog R., Andersson A. The management of radioactive waste. A description of ten countries. - Stockholm: Swedish Nuclear Fuel and Waste Management Co., 2000. - 112 p.

6. Von Berlepsch T., Haverkamp B. Salt as a host rock for the geological repository for nuclear waste // Elements. - 2016. - Vol.12. - No. 4. - P.257-262.

7. Hedin A., Olsson $O$. Crystalline rock as a repository for Swedish spent nuclear fuel // Elements. - 2016. - Vol.12. No. 4. - P.247-252.

8. Rempe N.T. Permanent underground repositories for radioactive waste // Prog. Nucl. Energy. - 2007. - Vol.49. P.365-374.

9. Pigford T.H. Geologic disposal of radioactive waste. Ethical and technical issues. - University of California Berkeley, 2000. - P.113-128.

10. Ewing R.C. Long-term storage of spent nuclear fuel // Nat. Mater. - 2015. - Vol.14. - P.252-257.

11. Swift P.N., Bonano E.J. Geological disposal of nuclear waste in tuff: Yucca Mountain (USA) // Elements. - 2016. Vol.12. - P.263-268.

12. Beate Kallenbach-Herbert. Radioactive waste management in Germany - recent developments based on lessons learnt. - Stockholm: Oko-Institut e.V., 2014. - 42 p.

13. Wang $Q$., Ni S. Solute transport in deep geology disposal of high radioactive waste // Chem. Eng. Trans. - 2018. - Vol.71. - P.781-786.

14. Inertization and reuse of waste materials by vitrification and fabrication of glass-based products / Colombo P., Brusatin G., Bernardo E., Scarinci G. // Curr. Opin. Solid State Mater. Sci. - 2003. - Vol.7. - P.225-239.

15. Donald I.W., Metcalfe B.L., Taylor R.N.J. The immobilization of high level radioactive wastes using ceramics and glasses // J. Mater. Sci. - 1997. - Vol.32. - No. 22. P.5851-5887.

Received 22.11.2019

M.V. Kustov, V.D. Kalugin, V.V. Deineka, G.M. Shabanova, A.M. Korohodska, E.D. Slepuzhnikov, D.M. Deyneka

\section{РАДІАЦЙНОЗАХИСНИЙ ЦЕМЕНТ ДЛЯ ДОВГОСТРОКОВОГО ЗАХОРОНЕННЯ РАДІОАКТИВНИХ ВІДХОДІВ}

М.В. Кустов, В.Д. Калугін, В.В. Дейнека, Г.М. Шабанова, А.М. Корогодська, Е.Д. Слепужніков, Д.М. Дейнека

Для підвищення безпеки експлуатації геологічних наддовгострокових захоронень радіоактивних відходів запропоноване оброблення стінок сховищ герметизуючим радіоаційнозахисним матеріалом. Для иього на основі сполук чотирикомпонентної системи $\mathrm{CaO}-\mathrm{BaO}-\mathrm{Fe}_{2} \mathrm{O}_{3}-\mathrm{SiO}_{2}$ розроблено технологію виробництва спеціальних корозійностійких цементів поліфункціонального призначення, які можуть використовуватись для одержання високоміцних радіоаційнозахисних та корозійностійких тампонажних бетонів. За допомогою термодинамічного методу аналізу встановлено фазові рівноваги та здійснено тетраедрацію системи при передбачуваній температурі синтезу $1200^{\circ} \mathrm{C}$ з метою мінімізування обсягів необхідних термодинамічних розрахунків. Досліджено процеси гідратації кальційбарієвого феросилікатного цементу і встановлено, що основними продуктами гідратації є гідросилікати барію та гідроферити кальцію $і$ барію різної основності, що забезпечує високі міцнісні характеристики иементному каменю. Одержані матеріали є високоміцними (міцність на стиск до 58,9 МПа), захисними (розрахунковий коефіцієнт масового поглинання до $247 \mathrm{~cm}^{2} /$ ) та корозійностійкими (коефіцієнт сульфатостійкості 1,31) иементами. Захисні бетони з різними заповнювачами, одержані на основі розробленого цементу, характеризу ються високою міцністю (межа міцності на стиск 58,4 МПа), невеликим ступенем розміцнення в інтервалі температур 20$1200^{\circ}$ С (до 15-19\%). Вони можуть застосовуватись при темnературах до $1200^{\circ} \mathrm{C}$.

Ключові слова: радіоактивні відходи, екологічна безпека захоронення, твердофазний синтез, в’яжучі матеріали, процеси гідратації, радіоаційнозахисні властивості. 


\section{RADIOPROTECTIVE CEMENT FOR LONG-TERM STORAGE OF NUCLEAR WASTE}

M.V. Kustov ${ }^{a,}{ }^{*}$, V.D. Kalugin ${ }^{a}$, V.V. Deineka ${ }^{a}$, G.M. Shabanova ${ }^{b}$, A.M. Korohodska ${ }^{b}$, E.D. Slepuzhnikov ${ }^{a}$, D.M. Deyneka ${ }^{b}$

a National University of Civil Defence of Ukraine, Kharkiv, Ukraine

b National Technical University «Kharkiv Polytechnic Institute», Kharkiv, Ukraine

* e-mail: kustov_m@nuczu.edu.ua

To enhance the service safety of the geological repositories which are intended for a highly long-term storage of nuclear waste, we proposed coating the walls of repositories with a hermetically sealed radiation-resistant material. To this end, the compounds of a four-component system $\mathrm{CaO}-\mathrm{BaO}-\mathrm{Fe}_{2} \mathrm{O}_{3}-\mathrm{SiO}_{2}$ were suggested. Based on these compounds, we developed the technology for the production of special polyfunctional corrosion-resistant cements that can be used for the production of extra strong radiation-protective and corrosion-resistant plugging cements. The thermodynamic analysis revealed probable phase equilibriums and enabled the tetrahedration of the system at the synthesis temperature of $1200^{\circ} \mathrm{C}$, which allowed minimizing the volume of required thermodynamic calculations. The processes of hydration of calcium-barium ferrosilicate cement were investigated. It was established that barium hydrosilicates and calcium and barium hydroferrites of a different basicity are the main hydration products; this provides high strength properties of the cement stone. The obtained materials are cements with a high strength (the compressive strength of $58.9 \mathrm{MPa}$ ), enhanced protective and corrosion-resistant properties (the calculated mass absorption coefficient and sulfate-resistance factor being equal to $247 \mathrm{~cm}^{2} / g$ and 1.31 , respectively). The protective concretes with different fillers, which were fabricated based on the developed cements, have a high strength (ultimate compressive strength of $58.4 \mathrm{MPa}$ ), a low level of softening in the temperature range of $20-1200^{\circ} \mathrm{C}$ (from 15 to 19\%). They can be used at the service temperature of up to $1200^{\circ} \mathrm{C}$.

Keywords: radioactive waste; environmentally safe disposal; solid-phase synthesis; binding materials; hydration processes; radioprotective properties.

\section{REFERENCES}

1. Mollah A.S. Overview of regulatory control for radioactive sources and nuclear materials for peaceful applications of nuclear technology. International Journal of Nuclear Law, 2009, vol. 2, no. 3, pp. 175-191.

2. Kustov M., Slepuzhnikov E., Lipovoy V., Khmyrov I., Dadashov I.F., Buskin O. Procedure for implementation of the method of artificial deposition of radioactive substances from the atmosphere. Nuclear and Radiation Safety, 2019, no. 3(83), pp. 13-25.

3. Aust M.O., Herrmann J., Summary of the situation of dumped nuclear waste in the North-East Atlantic Ocean. OSPAR Commission, 2013. 29 p.

4. Borowski G., Wosko M. Ecological and technical requirements of radioactive waste utilisation. Journal of Ecological Engineering, 2013, vol. 14, no. 1, pp. 40-47.

5. Lidskog R., Andersson A., The management of radioactive waste. A description of ten countries. Swedish Nuclear Fuel and Waste Management Co., Stockholm, 2000. 112 p.

6. Von Berlepsch T., Haverkamp B. Salt as a host rock for the geological repository for nuclear waste. Elements, 2016, vol. 12 , no. 4 , pp. 257-262.

7. Hedin A., Olsson O. Crystalline rock as a repository for Swedish spent nuclear fuel. Elements, 2016, vol. 12, no. 4, pp. 247-252.

8. Rempe N.T. Permanent underground repositories for radioactive waste. Progress in Nuclear Energy, 2007, vol. 49, pp. 365-374.

9. Pigford T.H., Geologic disposal of radioactive waste. Ethical and technical issues. University of California Berkeley, 2000, pp. 113-128.

10. Ewing R.C. Long-term storage of spent nuclear fuel. Nature Materials, 2015, vol. 14, pp. 252-257.

11. Swift P.N., Bonano E.J., Geological disposal of nuclear waste in tuff: Yucca Mountain (USA). Elements, 2016, vol. 12, no. 4 , pp. 263-268.

12. Beate Kallenbach-Herbert, Radioactive waste management in Germany - recent developments based on lessons learnt. Oko-Institut e.V., Stockholm, 2014. 42 p.

13. Wang Q., Ni S. Solute transport in deep geology disposal of high radioactive waste. Chemical Engineering Transactions, 2018, vol. 71, pp. 781-786.

14. Colombo P., Brusatin G., Bernardo E., Scarinci G. Inertization and reuse of waste materials by vitrification and fabrication of glass-based products. Current Opinion in Solid State and Materials Science, 2003, vol. 7, pp. 225-239.

15. Donald I.W., Metcalfe B.L., Taylor R.N.J. The immobilization of high level radioactive wastes using ceramics and glasses. Journal of Materials Science, 1997, vol. 32, no. 22, pp. 5851-5887. 